\title{
Severe hypercalcemia due to the vitamin D intoxication presenting with acute renal failure
}

\author{
Hande Peynirci¹, Pınar Sisman², Fethullah Aydın³, Canan Ersoy², Erdinç Ertürk² \\ ${ }^{1}$ Kastamonu State Hospital, Kastamonu, Turkey \\ 2Department of Endocrinology and Metabolism, Uludag University Faculty of Medicine, Bursa, Turkey \\ ${ }^{3}$ Department of Internal Medicine, Uludag University Faculty of Medicine, Bursa, Turkey.
}

Hypervitaminosis $D$ is a rarely reported condition. It may be observed more frequently because of the recent increase in supplement use of vitamin $D$ and should be included in the differential diagnosis of hypercalcemia (1). Herein, we report a case of vitamin $D$ intoxication which was the first case with this high level of calcium as we searched the literature $(2,3)$.

A 57-year old hypertensive woman admitted to our emergency room with symptoms of lethargy, pain in the abdomen, constipation, loss of appetite and confusion. Blood pressure, heart rate, and body temperature of the patient were $150 / 90 \mathrm{mmHg}, 62$ beats/min, and $36.6^{\circ} \mathrm{C}$, respectively. No other systemic abnormalities were observed except dried mucous membranes and decreased skin turgor tonus. Routine chemistry revealed; glucose $98 \mathrm{mg} / \mathrm{dL}(70-100 \mathrm{mg} / \mathrm{dL})$, urea $88 \mathrm{mg} / \mathrm{dL}(10-50 \mathrm{mg} / \mathrm{dL})$, creatinine $3.4 \mathrm{mg} / \mathrm{dL}(0.6-1.3 \mathrm{mg} / \mathrm{dL})$, total protein 7.0 $\mathrm{g} / \mathrm{dL}(6.3-8.3 \mathrm{~g} / \mathrm{dL})$, albumin $3.8 \mathrm{~g} / \mathrm{dL}(3.5-5.0 \mathrm{~g} / \mathrm{dL})$, serum calcium $22,7 \mathrm{mg} / \mathrm{dL}$ $(8,4-10,2 \mathrm{mg} / \mathrm{dL})$, serum phosphorus $2,5 \mathrm{mg} / \mathrm{dL}(2,3-4,7 \mathrm{mg} / \mathrm{dL})$. Chest X-ray and the renal ultrasound was normal. Corrected QT was found $260 \mathrm{~m} / \mathrm{sec}$ in electrocardiography.

The patient reported that she had been operated due to diagnosis of multinodular goiter and hypothyroidism and hypoparathyroidism had developed postsurgically. She admitted to the outpatient clinic of internal medicine in another hospital one month ago with a calcium value of $7.6 \mathrm{mg} / \mathrm{dL}$. At the time of admission, she was taking calcium $4000 \mathrm{mg} / \mathrm{d}$, cholecalciferol $3520 \mathrm{IU} / \mathrm{d}$, calcitriol $0.5 \mathrm{mcg} / \mathrm{d}$. Treatment was changed as calcium $6000 \mathrm{mg} / \mathrm{d}$, cholecalciferol $5280 \mathrm{IU} / \mathrm{d}$, calcitriol $1 \mathrm{mcg} / \mathrm{d}$. She was on $125 \mu \mathrm{g}$ L-thyroxine therapy with a thyroid stimulating hormone (TSH) level of $2.4 \mu \mathrm{IU} / \mathrm{mL}(0.35-4.94 \mu \mathrm{IU} / \mathrm{mL})$.

The patient was hospitalized to our endocrinology clinic and taken to the low calcium hemodialysis. After hemodialysis, her calcium level decreased to $13.7 \mathrm{mg} /$ $\mathrm{dL}$. Then she was managed by continuous saline infusion and diuretics. The level of serum calcium, phosphorus and creatinine level was $8.5 \mathrm{mg} / \mathrm{dL}, 2.7 \mathrm{mg} / \mathrm{dL}, 1.1$ $\mathrm{mg} / \mathrm{dL}$, respectively on the $8^{\text {th }}$ day of treatment.

Conclusion:

\section{References:}

Vitamin D supplementation should be appropriately monitored due to potential risk of intoxication.

1.Jones G. Pharmacokinetics of vitamin D toxicity. Am J Clin Nutr. 2008;88(2):582S-586S. Review.

2.Marins TA, Galvão Tde F, Korkes F, et al. Vitamin D intoxication:case report Einstein (Sao Paulo) . 2014; 12(2): 242-244

3.Naik MA, Banday KA, Najar MS, Reshi AR, Bhat MA. Vitamin D intoxication presenting as acute renal failure Indian J Nephrol. 2008;18(3): 125-126. 